\title{
Technology Appropriation in the Chilean-Mapuche Territorial Conflict: The Case of the Mapuche Digital Media Werken.cl ${ }^{1}$
}

\author{
Juan Alfredo DEL VALLE ROJAS, PhDc \\ Department of European Languages and Cultures \\ Graduate School for the Humanities \\ University of Groningen, the Netherlands \\ E-mail: j.a.del.valle.rojas@rug.nl
}

\begin{abstract}
This work aims at visualizing the frames of significance that are present in the informative discourses, as well as the constructions about the Mapuche territory appearing on the Mapuche digital media Werken.cl. Territory is enrolled in a significance system that legitimates the processes of territorial recovery, contrary to the Chilean State's position representing it as the manifestation of terrorist and violent acts. The results show that there is a system of significance about territory presented in the informative discourses that legitimizes territorial recovery as committed to a decolonial project whose purpose is to transform the system of relations imposed by the coloniality in the context of the Chilean-Mapuche conflict.
\end{abstract}

Keywords: Territory; Reclaiming; Mapuche; Digital Media; Decoloniality.

1 Some previous articles closely related to this work have been published in Latin America: Del Valle, J. (2016). El discurso informativo del periodico digital Mapuche Werken.cl en torno al territorio: una lectura decolonial del conflicto entre el Estado-Nación chileno y el Pueblo Mapuche. [Master Thesis] University of La Frontera, Temuco- Chile; and Del Valle, J. \& Maldonado, C. (2016). El discurso del periódico Mapuche Werken.cl sobre el territorio: una lectura semiótico-decolonial, Chasqui. Revista Latinoamericana de Comunicación, 132. 
Acknowledgement: Fondecyt de Iniciación Project № 11140180: “Apropiación tecnológica, discurso y decolonialidad: la producción informativa digital Mapuche en el marco del conflicto entre el Estado-nación y el pueblo Mapuche en la Región de la Araucanía", funded by the Chilean Government (2014-2017).

\section{Introduction}

In the southern part of Chile, there are several ethnic minority movements to the indigenous inhabitants called the Mapuche, who have been defending and recovering their ancestral territory in order to be again recognized as an autonomous nation. This process of recovering usurped territory (among many other demands, such as revitalizing Mapuche language and obtaining political representation in the Parliament) is known as the Chilean-Mapuche conflict. Consequently, different Mapuche movements have been carrying out different control procedures such as the recovery of usurped territories suffered from the colonialist policies of Chile and the plan of modernization of the country (Pinto, 2003). This ancestral territorial recovery emerges as a proposal of sovereign reconstruction for the Mapuche Nation which sets the political-identity agenda of several Mapuche movements. The Mapuche movements aim at achieving the recognition of culture and territory in society while it is identified the long-term abuse suffered from the colonial matrix of power imposed by the Chilean State.

This current social and cultural scenario provides several possibilities in struggle for identity and cultural reaffirmation, as well as the context defined by the centrality of information (Castells, 2009), which has a central role when legitimizing their own reclaiming processes. In response to those regimes of representation established by the authority discourses against indigenous people, and considering the features that define the Network Society, and their possibilities of selfcommunication (Castells, 2009), it has emerged several alternatives of indigenous communication in Latin America which are situated in the hyper-mediatic sphere as narratives confronting the coloniality of power-knowledge-being.

Considering the above, my objective will be to address the following research question: Which are the frames of significance presented in the discourse of the different digital media newspapers that are being built on territory in the context of the Chilean-Mapuche conflict? In order to answer this question, I will focus on the understanding of the discursive construction around the topic of territory considering the several dimensions of such disputes in the context of the Chilean-Mapuche conflict. In particular, I will analyze the informative production of the Mapuche digital media Werken.cl (www.werken.cl) $)^{2}$ as it mainly covers top-

2 The Mapuche digital media Werken.cl was launched in 2012. However, the website was created in December 2014. According to their own communicators, it emerges around the need 
ics related to the reclaiming of the ancestral Mapuche territory and its worldview using the news as a tool for political-identity reclaim of the different Mapuche movements and communities in Chile (Del Valle and Maldonado, 2016). Specifically, I will compare the informative production related to the topic of territory in the context of the Nation-State-Mapuche conflict presented in the Mapuche digital media Werken.cl in 2015 and 2018. In line with this, I present three main objectives: 1) Understand the informative discourses in the Mapuche digital media Werken. $\mathrm{cl}$ on territory within the context of the Chilean-Mapuche conflict; 2) Identify the discursive, factual and significant elements within the informative discourse of the Mapuche digital media Werken.cl on the territory; 3) Interpret the results of the analyses as of the argumentative and conceptual keys from the decolonial turn.

\section{The Concept of Territory as a Field of Dispute}

Territory is a very broad concept in terms of its definition. Generally speaking, Chilean State considers it as a limited space under control of a group of people who comprise the extension of State power (Elden, 2013). Therefore, it assigns a geographical space of administrative and economic value to the territory emphasizing the idea of sovereignty and national unity. This Western view of territory states that territorial spaces are valuable resources for dominating, exploiting, and transforming as part of an instrumental rationality grounded to modernization as a global Western project (Le- Bonniec, 2002).

Regarding several studies on the representation of territory in ethnic minorities, I highlight Molina's use of the concept of etno-territories (1995) defined as areas inhabited by indigenous peoples or ethnic minorities which are characterized for both being delimited in geographical boundary markers and socially recognized for communities of the same or a different ethnic group. He also argues that indigenous peoples assign to territory a political, economic, social, cultural, and religious value. Within the context of the Mapuche people's conception on territorial identities, Le-Bonniec (2002) states that there is a difference in terms of the content of the word when Chilean and Mapuche people perceive the land. Besides, he argues that Chilean people conceive land as a common piece of field containing an economic and interchangeable value. On the contrary, Mapuche people conceive land as a necessary and essential space for the development and transmission of the ancestral culture. Finally, we can mention Álvaro Bello's contribution (2004) defining territory as a social construction which is the result of several ways of

of covering the news occurring in the Mapuche communities, which were not covered by the traditional hegemonic newspapers. Therefore, the news covered by the Werken.cl are located in the Wallmapu (in Mapuzungun, the Mapuche ancestral language, it refers to the territory that has historically belonged to the Mapuche people in Chile). 
space appropriation joining several actors through their historical experiences. Besides, he points out that this construction of territory emerges from the hegemonic dispute for space in response to different struggles and interests. Bello refers to territory as a field of the dispute between the State-Nation and the Mapuche people, which has become into a key concept for Mapuche people when understanding the relations among geography, culture, politics, and nature.

For a better understanding of the concept of territory, it is essential to differentiate among the concepts of land, territory, and property. As pointed out by Margaret Moore (2015), land refers to the portion of the earth that is not covered by water. On the other hand, territory refers to the geographical domain of a political entity, most of the time, the State. Finally, property refers to a complex collection of rights, moral powers, privileges, and duties that are given to the owner of the moral and legal rights in order to access and controlling the objects and excluding the others from them (Moore, 2015). In line with this, Gilberto Giménez (1996) states that territory exists as long as it is valued in different ways, such as a source of economic resources, political-administrative circumscription, means of livelihood, or a space of inscription of a historical past and a symbol of socio-territorial identity as well, as in the case of the Mapuche people. Territory is, then, a historical and cultural space, since this is a space joining biological, social, economic, political, psychological, and cultural factors (Gallastegui, 2012). In relation to this, Juan Echeverri (2005) argues that there are two general senses about the concept of territory: 1) as a political-jurisdictional sense, understood as the geographical space which defines or delineates sovereignty of a political power that can be seen nowadays as a national territory structured by a closed border, polygonal, delineated, and protected in its borders territory through physical barriers and armies; 2) territory deriving from the natural sciences, referring to the protection of a space where individuals or species reproduce and get their resources.

It is also important differentiate the concepts of territory and territoriality. In this regard, Kevin Cox (2002) points out that they both are two concepts of political geography linked to the ides of power and space: territories as spaces that are defended, completed, claimed against others' claims, specifically through territoriality. Therefore, territory cannot exist without territoriality. It is the activity of defending, controlling, and excluding; meanwhile, the territory is the area whose content we seek to control in a certain way.

Territoriality is defined by signals, such as marks of occupation, reactions to intruders, real or ritualized combats, etc. On the contrary, territory, in this sense, can be delimited (Echeverri, 2005). Regarding these concepts of territory and territoriality, the latter refers to the process of social practices and strategic social reproduction that are seeking the dominance over other groups of the population. Territory is a codified space, which is structured by several systems of social 
regulations that are seeking to achieve their objectives. Furthermore, territory is the result of a set of relations of power sustaining a determined economic infrastructure that, at the same time, is regulated by access and exclusions (Raffestin, 1988). Therefore, territory is perceived as a product, a mean of production, and an instrument used by the State-Nation in order to control the individuals, which entails that a hegemonic group influences its relation with its subalternized classes (Foucault, 2014). Raffestin (1988) states that territoriality is established by relation systems that subjects keep with exteriority and alterity in order to guarantee his/ her autonomy receiving support from certain mediators on society. This territoriality is submitted to productive and reproductive dynamics of territory assuming that territory as a whole is submitted to a logic of territorialization - deterritorialization - reterritorialization (Raffestin, 1988, 49). On the other hand, Sack (1986, 9) argues that territoriality is the "spatial strategy to affect, influence, and control resources and population by means of controlling a determined area", that is, controlling territory.

\section{The Notion of Territory in the Mapuche People's View}

Mapuche people (people of the land, in Mapudungun, the Mapuche ancestral language) identify territory as the basis of their existence and culture. They consider land and animals as part of every Mapuche clan and family. The Mapuche territory is called Wallontu Mapu or Wallmapu, which means surrounding earth. It comprises an area ranging from center-south parts of Chile and Argentina. Chilean part is named Ngulu Mapu while Argentinian one is known as Puel Mapu (Consejo Nacional de la Cultura y las Artes, 2012). According to the Mapuche worldview, the Report of the Historical Truth and New Deal for Indigenous Peoples (2003) states that Wallmapu is a wide and complex concept for Mapuche people. It is emphasized that the concept Wallmapu is understood as a whole, the one that embraces the manifestation of newen (referring to force or energy in Mapuzugun) in its different dimensions, which leads to a duality of the concept Wallmapu in its immaterial form associated to the territorial dimension where energies live and are developed. Territory for the Mapuche people is a territorial base, which is occupied by a determined space and its determined symbolic construction given to this territorial space. The boundaries of those territories rely on the way the che (human being) is related to the mapu (land). It is always related to the triangulation among land, human being, and nature (Crow, 2013). The definition of territory emerges from the beginning of the Mapuche people as a society, where it was understood under the concept of Futa Eln Mapu. Here, territory is related to materiality, but also to a spiritual relation that, at the same time, is part of territory limited by the human being, which is converted into a jurisdictional expression of territory carrying out several names, such as: Lof, Rewe, Ayllarewe, Futamapu, or 
Futa Eln Mapu. Likewise, Futa Eln Mapu comprises several Mapuche territories; they are Lafkenche, Williche, Pewenche, and Ngeche (Salamanca et al., 2003).

\section{Re-Reading Territory: Approaching from the Post-Development}

As stated by the Chilean historian Jorge Pinto (2003), Mapuche people were dispossessed from their territory because of the Chilean's purpose of controlling territory and population in order to articulate the economy to the circuits of capitalism. This idea of prosperity and control of the land came up after the constitution of Chile as a sovereign State-Nation. After that, they were convinced that development was the only possible way, a kind of salvation from underdevelopment and, at the same time, an inspiration to achieve prosperity of a modern country (Escobar, 2004). Occupation and usurpation of territory belonging to Mapuche communities are being carried out by a process of the legitimacy of the national development project that established the foundational basis of internal colonialism in detriment to Mapuche people. This domain of territorial space operates as profound epistemological device of Eurocentrism from Chilean elite in order to vanish or make the invisible Mapuche culture of its nature (Escobar, 2004). This is a post-developmental view of territory. Currently, the Mapuche reclaiming territorial struggle is focused on a reconstruction project of sovereign fabric whose main dimension of political and identity agenda is territorial recovery. Territory is a key element for the reconstruction of Mapuche country and a foundational dimension of its values and beliefs system. Therefore, it is certain that its defense of territory corresponds to a symbolic dimension of culture understood as if this is an ancestral, identity, cultural, and worldview element farther than it is understood in terms of semiosis by Western society. In this context, the Mapuche territorial struggle must be assumed as Mapuche culture's agency of vital projection (Flores, 1996). It attributes to the territory as the essential component for its politicaleconomic, modernist, and developmental project. On the contrary, it emerges a critical claim from Mapuche movements against the Chilean State about development and modernization of the country by searching for a post-developmental alternative to the prevailing capitalist model (Escobar, 2004). From a Western perspective, territory is a geographical space of economic and administrative value contingent upon national unity, sovereignty, and commodification ideas through the exploitation of their own natural resources. Accordingly, the reclaiming and recuperation of ancestral territories by Mapuche movements is expressed through an antagonist dispute of the colonial and capitalist matrix that has historically sustained the civilization project of the global West.

In several Latin American indigenous peoples, territory is part of the worldview named Sumak Kawsay. It is also known as Buen Vivir (Good Living), which is a Quechua word referring to an ancestral worldview of life. This Good Living view is 
being considered within a process of developmental reconceptualization in some countries, such as Ecuador, Bolivia, and Venezuela. These countries have incorporated the notion of Good Living in their plans of development, objectives, discourses, and legal frameworks of national constitutions. From this other-worldview, environment must be considered as "a fertile and healthy territory where cultivating as required in a diverse way; to preserve, to look after, to keep lakes, rivers, forests, mountains, and air all clean; to have a collectively managed territory, an education based on their own values and a sustained communication [Juan del Valle]" (Chuji, 2010). Consequently, Good Living is agreed as a holistic concept deeply rooted in the principles and values such as harmony, balance, and complementarity, which must guide the relationship among human beings by them, Mother Earth, and the cosmos. Mapuche identity, which is always connected to earth and nature, is perpetually linked to the sacred through its ways of representation and its ancestors. Thus, Mapuche people conceive Kyme-Mogen (Good Living in Mapudungun) as a permanent relation with nature, $\mathrm{n}$ harmony and balance with Mother Earth, to live with no violence, with affect and empathy. According to Massoni (2003), Kyme-Mogen, as part of its guidelines of Good Living's philosophy, proposes establishing values of empathy, respect, not violence, and keeping a relation of reciprocity with the earth by taking from it not more than you need. This relation of balance and harmony with Mother Earth and the close relationship between cultural identity and earth in Mapuche people's worldview is different from Andean peoples' view in terms of keeping beliefs in a different omnipotent Good, which is appropriately proved in the literal meaning of the Mapuche word: People of Earth.

Mapuche people was imposed a cultural and ideological repertoire that created a cultural shock regarding the conception of territory. As argued by Zúñiga (1998), Mapuche people have neither incorporated the concept of property nor accumulation of material resources. Thus, the dispute involves an economic factor which brings into a struggle against both internal colonialism and global Coloniality of Power conveyed by the forces of the mercantile empire of world capitalism. In this context, Mapuche people express demands supported by indigenous peoples' regulations in order to claim usurped territory in relation to two dimensions: The dimension of space demanding natural resources management and use; and the dimension of the process allowing to control the Mapuche people's political, economic, social, and cultural order processes. As considered by several Latin American indigenous communities, Mapuche communities started to "consider strategies to reinforce control over territory; displacement prevention; and the right of peace, freedom, and life in collective territories" (Escobar, 2014, 71). Therefore, Mapuche people demand the rights to self-determination through the right of recovering ancestral territory arguing as a people with the legitimate right to space to recover sovereignty. 
Regarding Mapuche people's territoriality, it is explained under a triple spatial dimension: as a material basis, geographical space and, at the same time, systemic component of resources; understood as social space which is built under Mapuche people's historical-cultural and symbolic influence; finally, it is understood as that geographical political space under political control of a people (Toledo, 2006). Consequently, Mapuche people's reclaiming process of territorial spaces responds to defense and resistance towards (capitalist and liberal) modernity expanding to the world through their own colonialist patterns primarily based on a dualist view of territory. That is, set apart human being, mind, and body for the purpose of achieving civilized, free, and rational world in their attempts to avoid those other forms of existing worlds (Escobar, 2014).

\section{Appropriation, Media, and Indigenous Journalism}

In order to get a better understanding of this work, it is worth to discuss two important studies closely related to the technology appropriation field: Ethnic Minority Media and Indigenous Journalism. The concept Ethnic Minority Media (EMM) refers to the process of media appropriation carried out by an ethnic minority committed to their own traditional values, which coexists with citizens of countries like Spain (Basques and Catalans), Turkey (Kurds), Greenland (Inuits), etc. All of them seek to legitimize their identity and culture in the face of the major mass media companies that usually ignore them or represent them as problematic groups (Riggins, 1992).

When analyzing the case of the Mapuche digital media, there is a clear coherence to the claims forms the concept of Ethnic Minority Media. These digital newspapers based on the symbolic flow spaces of the digital era are intended to configure alternative/alterative narratives regarding the hegemonic discourses from the symbolic elites. Riggins (1992) remarks that the traditional mass media ignore the minority ethnic groups and in some cases classify them as problematic actors in the middle of the predominant social structure. Thus, the Mapuche digital media locate the issues of the Mapuche indigenous world from the episteme that contribute to strain the normative semiosphere related to its identity/alterity by expanding the systems of significance in connection with its own case.

Regarding Indigenous Journalism, Tabares (2012) states that the key premise is to explain the crisis of the West assuming its design as a fundamental tool to identify and value other ways of civilizing construction which, at the same time, is demanding other-communications that allows to face coloniality. According to the Peruvian sociologist Aníbal Quijano $(2007,93)$ coloniality refers to "one of the constitutive and specific elements of the worldwide pattern of capitalist power". He adds that "it is sustained in the imposition of a racial/ethnic classification of the population around the world, acting as a cornerstone of this pattern of power, 
which operates in each of the materialistic and subjective fields, areas, and dimensions of the daily existence in a social scale" (Quijano, 2007, 93). In these terms, the process of technology appropriation carried out by the Mapuche communicators is intended to decolonize the imaginaries imposed by the nationalist pedagogies generating archives that sub-ontologize the Mapuche throughout history.

Regarding the political-cultural struggle experienced by the Mapuche people, I can state that several Mapuche movements have been appropriating the digital platforms as a form of informing from alterity facing the preponderance of the mass media which, in turn, are aligned to the transnational companies' interests (Maldonado, 2010). In this context, Mapuche communicators cover the ChileanMapuche conflict where they are enrolled in such informative topics such as: the struggle for territorial claiming, the oppression of the State to the Mapuche people and their discussion for autonomy, the injustice of the State in the case of the judicial execution of the Mapuche people being accused of committing "terrorist acts", among others.

Several approaches to the study of Mapuche informative discourses presented in the digital spaces carried out by Maldonado (2010, 2012a, 2012b, 2014, 2015), Maldonado and Del Valle (2011, 2013), and Juan Del Valle and Maldonado (2016) confirm the presence of hypertextual narratives that put a strain on the hegemonic discourses contributing to reproducing the colonial imaginary locating Mapuche people as a radical-other in terms of the Chilean identity (Maldonado \& del Valle, 2013). This informative production carried out by the Mapuche communicators is key for understanding the Mapuche conflict since it establishes several kinds of understanding reality that has historically been silenced and/or excluded. In fact, these social discourses can be defined, as stated by the Belgian-Canadian social theorist Marc Angenot (1998), as a heteronomy, that is, discourses reporting hegemonic representations resulting from the contexts of production articulated in terms of a struggle for the hegemony. Therefore, it refers to the struggle for destroying the colonial matrix of power ruling the relation between the Chilean Nation-State and the Mapuche people.

\section{Methodology}

This work presents the analysis of the corpus using a comparative approach corresponding to the coverage of one year of informative production of the Werken.cl in 2015 and three months of coverage in 2018. Thus, the study is based on the analytical-interpretative qualitative methodology using a specific analysis model: The Analytical, Critical and Complex Matrix of Discourse ACCD (Del Valle, 2006). These are the levels in the ACCD:

1. Construction of the facts in the discourse: strategies for the elaboration of factualities (Potter, 1998). Empiricist discourse (a reference to "empirical data"); 
Fabrication of consensus (expressions related to previous social consensus); Use of details in narration (specific details in communication); Maximization/Minimization (most and less urgent expressions); Normalization/Non-normalization (normal and abnormal discourse).

2. Roles, actors, time/space, thematic values, and symbolic universe (Martín Serrano, 2004 and 1993; Giroud and Panier, 1988; Vega, 1986, 44). Role (role of actors in the narration); Actors (different characters, institutions, etc.); Space/Time (when and where it happens); Thematic Values (classified, ordered determined actors, times, places); Symbolic Universe (different systems-actors appearing in the text).

3. Narratological level and narrative paths (Giroud and Panier, 1988). Manipulation Phase (persuasion by threatening, seducing, etc.); Competence Phase (identifying features that make an actor manipulates another); Performance Phase (identifying transformations of actor-system); Penalty Phase (identifying possible consequences).

4. Logical-semantic or semiotic level (Giroud and Panier, 1988; Greimás and Courtés, 1982). A (presented as essence); No A (negation of A); B (alternative to the essence); No B (negation to B); Contrariety (story present as essence); Contradiction (negation of contrariety); Complementarity (story present an alternative to essence).

5. Tetralemic-complexity level of contents (Villasante, 2006; Ibáñez, 1994; Greimás and Courtés, 1982). Truth (related to the essence of the story); Falsehood (negation of that essence); Lie (a false according to the story); Secret (hidden elements to manipulate the story).

The obtained results will be interpreted using the Creative Synthesis in order to articulate them with conceptual categories that will produce the theoreticalconceptual epistemological matrix for this work. For the process of selecting the suitable Mapuche digital media, it was stated the following inclusion/exclusion criteria:

a. A digital informative media carried out by Mapuche communicators with a political-identity statement associated to the claiming of the autonomous Mapuche movement.

b. A digital media informing and covering news in the Mapuche territory, specifically Temucuicui and Ercilla communities (two communities where violence is high due to the process of recovering usurped territory and its consequent violent response of the Government sending policemen who violently repress any kind of recovering process).

The selection of the corpus analysis corresponds to the coverage of one year of informative production in 2015, which is compared to the corpus analysis corresponding to the coverage of three last months of informative production in 2018. 
There were two hundred and twenty news, from which twenty-one were selected (See: Appendices) according to the following criteria:

a. Classification of themes: State-nation and Mapuche people conflict in La Araucanía Region (the place where most of the Mapuche people are settled).

b. Sub-theme: Territory.

c. Coverage: The occupation of the land and forced evictions in 2015 and 2018.

d. Journalism genres: Given the features of this digital media in terms of its production of news, it will be analyzed the informative texts

e. Type of text: News.

The relevance of the corpus refers to the explicit struggle for territory by Mapuche communities, as in the case of the occupation of the land and the consequences like forced evictions of that occupied land by Chilean State.

\section{Results}

As a result, I will present the collected information on the basis of three main systems of significance in order to provide a coherent analytical-interpretative reading of the creative synthesis and conceptual categories to the theoretical-conceptual framework of this research with the obtained results by using the Analytical, Critical and Complex Matrix of Discourse (For further information, see Appendices).

\section{Territorial Usurpation Scope}

This system of significance establishes the strained relations between the Nation-State and Mapuche people as agent systems. Within the context of the territorial usurpation carried out by the Chilean government, this thrust emerges as the generator of a semiosis linked to the complaint of coloniality and the prospect of a Mapuche sovereignty as a decolonial project. Therefore, this reclaim of territory is also a defense and resistance of modernity capital system that operates through coloniality around the world mainly seeking to impose a liberal civilization model avoiding any other kind of constructions of the reality (Escobar, 2014). Those results from the analysis signify in a historical process that has ruled the relation between the State-Nation and the Mapuche people. Chilean historians Jorge Pinto (2003) and José Bengoa (1996) argue that since the beginning of the confirmation of the Chilean State-Nation, its relation with the Mapuche people has been characterized by a displacement policy-making with the territorial dimension as the central axis of these processes. From the Mapuche intellectuals (Nahuelpan, 2012; Mariman, Caniuqueo, Millalén, Levil, 2006), usurpation is assumed as part of a colonial state matrix that has operated to a structural level either in a physical sense and the subjectivity of the Mapuche people: "we refer to the formation of the State linked to a several processes of usurpation [that refers] either the accumulation of political, economic, and/or symbol- 
ic power of colonial order, derived from the conquering act and territorial or material usurpation practices that made or are making it possible [Juan del Valle]" (Nahuelpan et al., 2012, 126).

This narrative shows a temporality that, within historicity, usurpation starts as a process pinned to coloniality of power, a regressive glance unveiling the historical processes that have been carried out throughout coloniality of power. At present, defense and territorial recuperation processes are imperative for the Indigenous peoples inhabiting Latin America. These political and identity reaffirmation processes show the emergence of a new sense of belonging assumed as collective life project as of "place-based identities" (Escobar, 2004, 22). In this context, Mapuche communicators generate a social discourse endorsed by the struggles for territorial recovery. Territory is then conceived as a central element of political-cultural construction to obtain sovereignty and reconstruct the Mapuche Country.

Regarding the topic of territorial usurpation within the discourses carried out by the Werken.cl, it may be perceived that informative discourses are present in different news related to the Mapuche communities' responses to the usurpation process suffered during the setting up of the Chilean State-Nation (when they decided to pacifically occupy the private companies). This occupation of the Mapuche communities is seen as the struggle to claim the territory that was taken from them in the processes carried out by the State-Nation during the setting up of the Chilean State and its occupying Mapuche territory policy-making.

\section{Sovereignty and Territory in the Reconstruction of the Mapuche Country}

Usurpation of territory carried out by the Chilean State-Nation can be conceived as a manifestation of Coloniality of Power operating in a Mapuche territorial control level interrupting in several dimensions such as: organization, ritual, spatial, symbolic, subjective, and so on. In other words, usurpation of the territory is not an isolated action of submission and control mechanisms, but it belongs to a system of heterarchical domination (Grosfoguel, 2005). This claiming for territory belongs to a project of reconstruction of sovereignty attached to the identity political agenda of Mapuche people. Mapuche movements are conducting a political-identity agenda that seeks to recover ancestral territories as vital spaces for the conservation of their identity and culture. This process aims to obtain constitutional recognition of Mapuche people (Mariman, 1994). This decolonial lecture of the informative discourses of the Werken. $\mathrm{cl}$ on territory is key to understand the configuration of the social semiosis that goes beyond the oppositional or complaint level in relation to the adjusting devices exerted by the State-Nation. These discourses report a heteronomous narrative that, when facing the regimes of representation in itself and their historicity, validate self-referential significance systems that diversify the representation field in itself and their connection with 
territory. Although the projection of history locates territory as central dimension of the reconstruction of the Mapuche sovereignty it, at the same time, is destabilizing the monotopic model imposed by the State-Nation's coloniality due to territorial and sovereignty recovery means the possibility of legitimizing difference and, thus, affecting the univocal schemes of representation, opting for pluriversality of the sense and convivial horizons.

\section{Territory, Culture and the Mapuche World}

This system of significance can be seen in the discourses that locate territorial recovery in the aspects that produce the Mapuche cultural matrix: ceremonial spaces, social organizational forms, ritual systems, individual-nature link. This is an important point as it demonstrates the significant attributions of territory that resignifies instrumental and developmental lectures that have been consolidated by the colonial-capitalist imaginary in relation to territory (exploitation space, accumulation, administration, among others). In line with this, the process of territorial recovery operates as a way of epistemic detachment (Mignolo, 2008) in the Eurocentric vision of State and, at the same time, re-thinking a new epistemology that could be located in a pluriversality of knowledge assuming its different ways of indigenous peoples' identity, history, and beliefs. Therefore, this Mapuche people's resignification of territory drives to a new way of pluriversal reality which is intended to get rid off subjugation to a universal way of thinking that excludes and subjugates the indigenous peoples' other modes of knowledge.

The territory is a key element of identity, worldview, and culture for the Mapuche people. The relation between individuals and their environment is under reciprocity, balance, and harmony logics between the human being itself and the Nuke Mapu (Mother Earth). Therefore, stories related to territorial recovery atomize certain meanings which complement the political struggle by means of absent/ present elements, that is, by using significance systems that could be explained in the story or be constructed as of interfering and contextualizing processes legitimizing specific features of the Mapuche culture. It is important to note that those discursive systems achieve interpretative schemes that require the "intercultural communicative competence [Juan del Valle]" (Rodrigo, 1999, 9). Notwithstanding, they demand the intercultural competence that can be attached to a conception of critical interculturality, legitimizing the options of transforming colonial order becoming from the historical subalternized groups. This advance towards critical interculturality makes it complex Alsina's proposal (1999) as it requires an ethical commitment of political subjectivities that not only recognize and interact to each other, but they are constructed all in all as different subjects opting for the transformation of the colonial order. 


\section{Discussion}

Regarding the research question guiding this work which is related to the frames of significance about the topic of territory presented in the discourse of the Werken.cl, it is established that there is a system of significance about territory within the informative discourses that legitimizes territorial recovery as committed to a decolonial project whose purpose is to transform the system of relations imposed by the coloniality in the context of the Chilean-Mapuche conflict. In this context, it is important to state that discourses not only work as sense forces contrary to the narratives given by the Chilean institutions sustaining the prevailing colonial imaginary about the Mapuche people. Moreover, it can be stated that claiming territorial process being carried out by the several Mapuche movements corresponds to a political-identity project that seeks the reconstruction of the Mapuche Nation (Del Valle \& Maldonado, 2016). In this reclaiming process, the Mapuche communicators are essential in looking for the understanding of reality through the social discourse that has always been silenced and excluded by the dominant coloniality in Chile. This social discourse of the Werken.cl involves another-way of understanding in terms of territory, an alternative understanding of the ways of rationality that have been imposed by the modernization project of the Global North.

During this claiming territorial process, interculturality is seen as a social project underlying the encounter with the Other, the searching for a construction of societies, relations, and new and different life conditions (Walsh, 2009). It is of the utmost importance to establish that the heteronomous dimension in those discourses introduces systems of significance within the information flow channels of the hypermediatized society which contribute to recognizing the legitimate existence of the locus of enunciation which, from the constitutive exteriority of the colonial control system, opens a social semiosis allowing other forms of construction of realities. From what is said and silence, those discourses are contributing to both redefining the representational regimes of the Mapuche people and setting relational models overlapped to the exclusion.

Regarding the discourse around the topic of territory, and the interpretation of the results obtained in the analysis as of the argumentative and conceptual keys from the decolonial thought in the Mapuche digital media Werken.cl, it is established that discourse operates in three different systems of significance which, at the same time, operate as dynamiting core in the discursive frame of the Werken.cl:

1. Territory as usurpation, which is signified in the historical relation between the Chilean Nation-State and the Mapuche people, by realizing of a policy of usurpation or dispossession based on the state colonial matrix.

2. Territory as sovereignty, by which it is organized the political identity dimension of the reconstruction of the Mapuche country in the discourse. 
3. Territory as symbolic dimension of culture, a significant dimension which transcends the instrumental and developmental lectures that colonial-capitalist imaginary has consolidated in terms of territory as exploitation accumulation, and administration spaces, offering other perspectives that resignify territory from the cultural matrix in charge of ordering the Mapuche worldview.

\section{References}

1. Angenot, M. (1998). Interdiscursividades. De hegemonías y disidencias. Universidad Nacional de Córdoba, Córdoba.

2. Bello, A. (2004). Territorio, Cultura y acción colectiva indígena: algunas reflexiones y representaciones (pp. 96-111). In José Aylwin (Ed.). Derechos humanos y pueblos indígenas, tendencias internacionales y contexto chileno. Temuco Chile, Institutos de Asuntos Indígenas, WALIR, IGWIA, 2004.

3. Bengoa, J. (1996). Historia del Pueblo Mapuche (Siglos XIX y XX). Ediciones Sur: Santiago de Chile.

4. Castells, M. (2009). Communication and Power. UK: Oxford University Press.

5. Chuji, M. (2010). Sumak Kawsay versus desarrollo. Conference at the VI Encuentro de la Coordinadora asturiana de ONGDs, Oviedo, España.

6. Consejo Nacional de la Cultura y las Artes. (2012). Conociendo la cultura Mapuche. Publicaciones Cultura: Chile.

7. Cox, K. (2002). Political Geography. Territory, State, and Society. USA: Blackwell Publishers.

8. Crow, J. (2013). The Mapuche in Modern Chile. A Cultural History. University Press of Florida.

9. Del Valle, C. (2006). Comunicación participativa: Estado-nación y democracia. Discurso, tecnología y Poder. UFRO Ediciones: Chile.

10. Del Valle, J. (2016). El discurso informativo del periodico digital Mapuche Werken. cl en torno al territorio: una lectura decolonial del conflicto entre el Estado-Nación chileno y el Pueblo Mapuche. [Master Thesis] University of La Frontera, TemucoChile. Retrieved from http://bibliotecadigital.ufro.cl/?a=view\&item=70 on November 2018.

11. Del Valle, J. \& Maldonado, C. (2016). El discurso del periódico Mapuche Werken.cl sobre el territorio: una lectura semiótico-decolonial. Chasqui. Revista Latinoamericana de Comunicación, 132.

12. Echeverri, J. (2005). Territory as Body and Territory as nature: Intercultural dialogue?. In Surrallés, A. \& García P. (Eds.) The Land Within. IWGIA (International Work Group for Indigenous Affairs): Copenhagen, Denmark.

13. Elden, S. (2013). The birth of territory. The University of Chicago Press: Chicago and London.

14. Escobar, A. (2004). Worlds and Knowledges Otherwise. The Latin American Modernity/Coloniality Research Program. Retrieved from http://www.unc.edu/-aescobar/ articleslengli.html on November, 2018. 
15. Escobar, A. (2014). Sentipensar con la tierra. Nuevas lecturas sobre desarrollo, territorio y diferencia. Medellín: Ediciones UNAULA.

16. Flores, J. (1996). Estado y sociedad mapuche: el caso de la comunidad José Llancao, Pentukun: 29-48.

17. Foucault, M. (2014). Security, Territory, Population. Lectures at the Collège of France 1977-78. Palgrave Macmillan: UK.

18. Gallastegui, J. (2012). Las ciencias sociales explicar o comprender. Ed. Punta Ángeles. Chile.

19. Giménez, G. (1996). Territorio y Cultura. Estudios sobre las culturas contemporáneas, 2(004): 9-30.

20. Grosfoguel, R. (2005). The implications of Subaltern Epistemologies for Global Capitalism: Transmodernity, Border Thinking, and Global Coloniality. In Richard P. Appelbaum and William I. Robinson (Eds.). Critical Globalization studies, New York / London: Routledge.

21. Informe del La Comisión Verdad Histórica y Nuevo Trato de los Pueblos Indigenas. (2003). Santiago de Chile, Informe de Chile.

22. Le-Bonniec, F. (2002). Capítulo 2: La identidades territoriales o Como hacer historia desde hoy día. In Morales, R. (comp.). Territorialidad Mapuche en el siglo XX. Temuco, IEI-UFRO, Ediciones Escaparate, 31-49.

23. Maldonado, C. (2010). La producción de sitios Web Mapuches como Discurso Público Hipermedial Mapuche en su carácter de Comunicación Intercultural Mediatizada y su vinculación con la Exomemoria en un proyecto de Transculturación a través de redes digitales. Razón y Palabra, 71.

24. Maldonado, C. (2012a). Narrativa audiovisual Mapuche en Youtube: Subalternidad en la red global. Revista Internacional de Comunicación Audiovisual, Publicidad y Literatura, 10: 547-557.

25. Maldonado, C. (2012b). Narrativa hipertextual Mapuche: reconstrucción contrahegemónica del archivo mnémico. Perspectivas de la Comunicación, 5(1): 17-26.

26. Maldonado, C. (2014). Decolonialidad en las redes virtuales: el caso de Azkintuwe [Doctoral Thesis]. Universidad Autónoma de Barcelona, España.

27. Maldonado, C. (2015). Decolonialidad, tecnología y comunicación. Un estudio de caso, Diálogos, Special Edition: 1-27.

28. Maldonado, C., \& Del Valle, C. (2011). Discurso público hipertextual Mapuche: Aproximaciones teórico-conceptuales. Question, 1(31).

29. Maldonado, C., \& Del Valle, C. (2013). Medios de comunicación y narrativas hipertextuales: lógicas del desplazamiento del "conflicto Mapuche" al espacio virtual. Andamios, 22: 283-303.

30. Mariman, J. (1994). Transición democrática en Chile. ¿Nuevo ciclo reivindicativo Mapuche?. Caravelle, 63: 91-118.

31. Mariman, P., Caniuqueo, S., Millalén, J. \& Levil, R. (2006). ¡... Escucha Winka...! - Cuatro Ensayos De Historia Nacional Mapuche y Un Epílogo Sobre El Futuro. LOM Editores. 
32. Massoni, A. (2013). El buen vivir para el Pueblo Mapuche. Retrieved from https:// discursosypracticasdelbuenvivir.wordpress.com/tag/kyme-mogen/ on November 2018.

33. Mignolo, W. (2008). La opción descolonial. Letral, 1: 4-22.

34. Moore, M. (2015). A Political theory of Territory. Oxford University Press.

35. Molina, R. (1995). Reconstrucción de los etno-territorios, Tierra, territorio y desarrollo indígena. Temuko, IEI.

36. Nahuelpan, H. (2012). "Formación colonial del estado y desposesión en Ngulumapu". Ta in fijke xipa rakizuameluwun. Historia, colonialismo y resistencia desde el país Mapuche. En Nahuelpán, H. et. al. Temuco: Ediciones Comunidad de Historia Mapuche: 123-156.

37. Quijano, A. (2007). Colonialidad del poder y clasificación social. In Castro-Gómez, S. \& Grosfoguel, R. (Eds.) (2007). El giro decolonial: reflexiones para una diversidad epistémica más allá del capitalismo global. Bogotá: Iesco-Pensar-Siglo del Hombre Editores.

38. Pinto, J. (2003). La formación del Estado, la nación el pueblo mapuche. De la inclusión a la exclusión. DIBAM, Santiago de Chile.

39. Raffestin, C. (1988). Le territoire, la territorialité et la niut. Actualites psychiatriques, 2: 48-50.

40. Riggins, S. (1992). Ethnic Minority Media: an international perspective. SAGE Publications, California.

41. Rodrigo, M. (1999). La Comunicación intercultural. Barcelona: Anthropos.

42. Sack, R. (1986). Human Territoriality: Its Theory and History. Cambridge University Press.

43. Salamanca et al. (2003). "Mapu küpal azkünun zügu: Manifestaciones del Derecho Propio Mapuche en los territorios Wenteche, Pewenche y Lafkenche". Retreived from www.mapuexpress.net/images/publications/23_9_2006_20_15_51_1.doc on November 2018.

44. Salazar, J. (2005). Indigenous media in Latin America, Códigos. Revista del Departamento de Ciencias de la Comunicación, 1(2): 51-68.

45. Tabares, G. (2012). Periodismo Indígena La minga de pensamientos y acciones sobre la comunicación indígena. FLACSO, Ecuador.

46. Toledo, V. (2006). Pueblo Mapuche Derechos Colectivos y Territorio: Desafíos para la sustentabilidad Democrática. LOM Ediciones.

47. Walsh, C. (2009). Interculturalidad, Estado, Sociedad. Luchas (de) coloniales de nuestra época. Quito, UASB-Abya Yala.

48. Zúñiga, G. (1998). Los procesos de constitución de Territorio Indígenas en América Latina. Nueva Sociedad, 53: 141-155. 


\section{Appendices}

These figures present a brief summary of the results from the ACCD analysis applied to the selected news from the Werken.cl

News 1: Title: Carabineros llega a resguardar a empresa Forestales en territorio Mapuche de Arauco.

\begin{tabular}{|l|l|}
\hline $\begin{array}{l}\text { Construction of the facts in the } \\
\text { discourse }\end{array}$ & $\begin{array}{l}\text { Territorial recuperation. Police violence. Chilean State is protecting the for- } \\
\text { est companies. }\end{array}$ \\
\hline Roles, actors, time/space & Mapuche communities. Police protects and safeguards forest companies. \\
\hline $\begin{array}{l}\text { Narratological level and narrative } \\
\text { paths }\end{array}$ & Reclaiming territory. Police protects and safeguards forest companies. \\
\hline Logical-semantic or semiotic level & Recuperation - Usurpation - Repression - Reporting repression. \\
\hline $\begin{array}{l}\text { Tetralemic-complexity level of } \\
\text { contents }\end{array}$ & $\begin{array}{l}\text { Chilean State oppresses Mapuche communities and protects forest com- } \\
\text { panies. }\end{array}$ \\
\hline
\end{tabular}

News 2: Title: Lof Marriao Collihuinca: Máxima represión en Lumaco Bajo.

\begin{tabular}{|l|l|}
\hline $\begin{array}{l}\text { Construction of the facts in the } \\
\text { discourse }\end{array}$ & $\begin{array}{l}\text { Police violence. Eviction of Mapuche communities which are recuperation } \\
\text { territory. Territorial recovery. }\end{array}$ \\
\hline Roles, actors, time/space & Mapuche communities. Police evicts Mapuche people from the farm. \\
\hline $\begin{array}{l}\text { Narratological level and narrative } \\
\text { paths }\end{array}$ & Violent eviction. Recuperation of territory. \\
\hline Logical-semantic or semiotic level & Occupation - Usurpation - Resistence - Repression. \\
\hline $\begin{array}{l}\text { Tetralemic-complexity level of } \\
\text { contents }\end{array}$ & Police violently evicts Mapuche communities. \\
\hline
\end{tabular}

News 3: Title: Comunidades Mapuche de Ercilla mantienen tomada oficina de la Conadi en Temuco.

\begin{tabular}{|l|l|}
\hline $\begin{array}{l}\text { Construction of the facts in the } \\
\text { discourse }\end{array}$ & Mapuche communities demanding the recuperation of usurped territory. \\
\hline Roles, actors, time/space & $\begin{array}{l}\text { Three communities of Ercilla borough. Office in the National Council of the } \\
\text { National Indigenous Development Corporation (CONADI). }\end{array}$ \\
\hline $\begin{array}{l}\text { Narratological level and narrative } \\
\text { paths }\end{array}$ & $\begin{array}{l}\text { Reclaiming usurped land. Occupation of the office at the National Council } \\
\text { of the National Indigenous Development Corporation (CONADI). }\end{array}$ \\
\hline Logical-semantic or semiotic level & Defence - Usurpation - Dispossession - Justice. \\
\hline $\begin{array}{l}\text { Tetralemic-complexity level of } \\
\text { contents }\end{array}$ & Accelerating the process of buying and delivering territories in the CONADI. \\
\hline
\end{tabular}

News 4: Title: PDI realiza violento allanamiento comunidades Mapuche del lof Yeupeco.

\begin{tabular}{|l|l|}
\hline $\begin{array}{l}\text { Construction of the facts in the } \\
\text { discourse }\end{array}$ & Breaking into residences in Mapuche communities in Ercilla. \\
\hline Roles, actors, time/space & Communities of Ercilla. Chilean police. \\
\hline $\begin{array}{l}\text { Narratological level and narrative } \\
\text { paths }\end{array}$ & Breaking into Mapuche communities in order to threaten them. \\
\hline Logical-semantic or semiotic level & Resistence - Repression - Occupation - Crime. \\
\hline $\begin{array}{l}\text { Tetralemic-complexity level of } \\
\text { contents }\end{array}$ & $\begin{array}{l}\text { Police breaks into residences in Mapuche communitites to avoid the pro- } \\
\text { cesses of recovering territory. }\end{array}$ \\
\hline
\end{tabular}


News 5: Title: Más de 30 comuneros de la comunidad Mapuche autónoma Licancura se toma fundo Ranquilko en Mulchen.

\begin{tabular}{|l|l|}
\hline $\begin{array}{l}\text { Construction of the facts in the } \\
\text { discourse }\end{array}$ & $\begin{array}{l}\text { Mapuche movement pacifically seizes the Rankilko farm. Mapuche move- } \\
\text { ment is pushing the State to make it bring back their usurped territories. }\end{array}$ \\
\hline Roles, actors, time/space & Autonomous community Licancura. Rankilko farm. \\
\hline $\begin{array}{l}\text { Narratological level and narrative } \\
\text { paths }\end{array}$ & Reclaiming land (territory) restitution. \\
\hline Logical-semantic or semiotic level & Occupation - Usurpation - Resistence - Repression. \\
\hline $\begin{array}{l}\text { Tetralemic-complexity level of } \\
\text { contents }\end{array}$ & $\begin{array}{l}\text { Mapuche movement pacifically seizes Rankilko farm to push the State to } \\
\text { bring back their territories. }\end{array}$ \\
\hline
\end{tabular}

News 6: Title: Comunidades Mapuches del Pilmaiken advierten que defenderán el espacio sagrado amenazado por central Hidroeléctrica.

\begin{tabular}{|l|l|}
\hline $\begin{array}{l}\text { Construction of the facts in the } \\
\text { discourse }\end{array}$ & $\begin{array}{l}\text { Mapuche community is avoiding the installation of the hydroelectric plant in } \\
\text { a sacred place. }\end{array}$ \\
\hline Roles, actors, time/space & Hydroelectric plant Pilmaiken. Mapuche Huilliche community. \\
\hline $\begin{array}{l}\text { Narratological level and narrative } \\
\text { paths }\end{array}$ & Defending and recovering ancient sacred spaces. \\
\hline Nivel semiótico & Resistence - Invasion - Autonomy - Dispossession. \\
\hline $\begin{array}{l}\text { Tetralemic-complexity level of } \\
\text { contents }\end{array}$ & Defending Mapuche rights to protect sacred spaces. \\
\hline
\end{tabular}

News 7: Title: Tras violento desalojo detienen al Werken mapuche Rodrigo Kuripan perteneciente a la comunidad Ranquilko.

\begin{tabular}{|l|l|}
\hline $\begin{array}{l}\text { Construction of the facts in the } \\
\text { discourse }\end{array}$ & $\begin{array}{l}\text { Seizing farm as a reivindicative act. Violent eviction of Mapuche community } \\
\text { by police. }\end{array}$ \\
\hline Roles, actors, time/space & Rankilko community. Private farm. Chilean police. \\
\hline $\begin{array}{l}\text { Narratological level and narrative } \\
\text { paths }\end{array}$ & Occupation of farming as an act of territorial reclaiming. \\
\hline Logical-semantic or semiotic level & Resistence - Repression - Reclaiming territory - Criminalization. \\
\hline $\begin{array}{l}\text { Tetralemic-complexity level of } \\
\text { contents }\end{array}$ & $\begin{array}{l}\text { Eviction of Mapuche community which was seizing a farm as an act of ter- } \\
\text { ritorial recovering. }\end{array}$ \\
\hline
\end{tabular}

News 8: Title: Colono que impidió recuperación de tierra Mapuche tiene prontuario paramilitar Terrorista.

\begin{tabular}{|l|l|}
\hline $\begin{array}{l}\text { Construction of the facts in the } \\
\text { discourse }\end{array}$ & $\begin{array}{l}\text { Mapuche community is occupying a farm as act of territorial recovering. } \\
\text { Violent repression of European settlers and police. }\end{array}$ \\
\hline Roles, actors, time/space & Mapuche community. European Settlers. Chilean police. \\
\hline $\begin{array}{l}\text { Narratological level and narrative } \\
\text { paths }\end{array}$ & $\begin{array}{l}\text { Mapuche community puts a Mapuche symbol in a farm as an act of territo- } \\
\text { rial recovering. }\end{array}$ \\
\hline Logical-semantic or semiotic level & Recuperation - Usurpation - Reclaiming territory - Violence. \\
\hline $\begin{array}{l}\text { Tetralemic-complexity level of } \\
\text { contents }\end{array}$ & Mapuche community is occupying a farm as an act of territorial recovering. \\
\hline
\end{tabular}


News 9: Title: Varios comuneros Mapuches resultan detenido tras una reivindicación Territorial.

\begin{tabular}{|l|l|}
\hline $\begin{array}{l}\text { Construction of the facts in the } \\
\text { discourse }\end{array}$ & $\begin{array}{l}\text { Mapuche community is seizing a farm as an act of territorial recovering. } \\
\text { Violent eviction of Mapuche people by the police: }\end{array}$ \\
\hline Roles, actors, time/space & Mapuche community. Huichahue farm. Chilean police. \\
\hline $\begin{array}{l}\text { Narratological level and narrative } \\
\text { paths }\end{array}$ & $\begin{array}{l}\text { Occupation of the farm as a mechanism of demanding the usurped terri- } \\
\text { tory. }\end{array}$ \\
\hline Logical-semantic or semiotic level & Reclaiming territory - Usurpation - Defence. \\
\hline $\begin{array}{l}\text { Tetralemic-complexity level of } \\
\text { contents }\end{array}$ & Occupation of a farm as a legal action to recover usurped territory. \\
\hline
\end{tabular}

News 10: Title: Colonos fuertemente armados y apoyados por Carabineros disparan a comuneros mapuche que reivindican fundo en Carahue.

\begin{tabular}{|l|l|}
\hline $\begin{array}{l}\text { Construction of the facts in the } \\
\text { discourse }\end{array}$ & $\begin{array}{l}\text { Mapuche community seizes Toquihue farm. Violent clash among Mapuche } \\
\text { movement, European settlers and the police. }\end{array}$ \\
\hline Roles, actors, time/space & $\begin{array}{l}\text { Mapuche community. European settlers (living in La Araucanía Region). } \\
\text { Chilean police. }\end{array}$ \\
\hline $\begin{array}{l}\text { Narratological level and narrative } \\
\text { paths }\end{array}$ & Occupation of the farm as a territorial recuperation process. \\
\hline Logical-semantic or semiotic level & Reclaiming territory - Usurpation - Defence - Repression. \\
\hline $\begin{array}{l}\text { Tetralemic-complexity level of } \\
\text { contents }\end{array}$ & Mapuche community seizes a farm as an act of territorial recovering. \\
\hline
\end{tabular}

News 11: Title: Más de 50 comuneros mapuche se toman predio de colonos y particulares en Ercilla.

\begin{tabular}{|l|l|}
\hline $\begin{array}{l}\text { Construction of the facts in the } \\
\text { discourse }\end{array}$ & $\begin{array}{l}\text { Mapuche community is recovering farms and supporting Mapuche groups } \\
\text { in hugner strike. Violent clash with the police. }\end{array}$ \\
\hline Roles, actors, time/space & Mapuche communities and the Chilean police. \\
\hline $\begin{array}{l}\text { Narratological level and narrative } \\
\text { paths }\end{array}$ & $\begin{array}{l}\text { Violent repression to Mapuche people who are recovering usurped territo- } \\
\text { ries and supporting Mapuche groups in hunger strike. }\end{array}$ \\
\hline Logical-semantic or semiotic level & Recuperation - Crime - Reclaiming territory - Criminalization. \\
\hline $\begin{array}{l}\text { Tetralemic-complexity level of } \\
\text { contents }\end{array}$ & $\begin{array}{l}\text { Mapuche community is recovering usurped territories and supporting } \\
\text { Mapuche groups in hunger strike. }\end{array}$ \\
\hline
\end{tabular}

News 12: Title: Comunidad Mapuche Lleupeco Wenteche se toman predios usurpados por la Familias Luchsinger.

\begin{tabular}{|l|l|}
\hline $\begin{array}{l}\text { Construction of the facts in the } \\
\text { discourse }\end{array}$ & $\begin{array}{l}\text { Mapuche community occupies a farm and commemorates the death of a } \\
\text { Mapuche fellow by the police. }\end{array}$ \\
\hline Roles, actors, time/space & Mapuche community, Luchsinger family, Chilean police. \\
\hline $\begin{array}{l}\text { Narratological level and narrative } \\
\text { paths }\end{array}$ & $\begin{array}{l}\text { Mapuche community seizes a farm with the purpose of pushing the State to } \\
\text { bringing back usurped territories. }\end{array}$ \\
\hline Logical-semantic or semiotic level & Occupation - Usurpation - Resistence - Repression. \\
\hline $\begin{array}{l}\text { Tetralemic-complexity level of } \\
\text { contents }\end{array}$ & $\begin{array}{l}\text { Mapuche movement suffers from a violent repression when occupying a } \\
\text { farm with the purpose of pushing the Sate to bringing back usurped terri- } \\
\text { tory. }\end{array}$ \\
\hline
\end{tabular}


News 13: Title: Llevan a juicios a 3 mapuches que lideran defensa del territorio y oposición a Hidroeléctrica.

\begin{tabular}{|l|l|}
\hline $\begin{array}{l}\text { Construction of the facts in the } \\
\text { discourse }\end{array}$ & $\begin{array}{l}\text { Mapuche communitites are avoiding the installation of a hydroelectric plant } \\
\text { in a sacred place. }\end{array}$ \\
\hline Roles, actors, time/space & Mapuche communities, hydroelectric plants, Chilean State. \\
\hline $\begin{array}{l}\text { Narratological level and narrative } \\
\text { paths }\end{array}$ & $\begin{array}{l}\text { Police detained a Mapuche person with the purpose of avoiding further } \\
\text { manifestations against the installation of the hydroelectric plant. }\end{array}$ \\
\hline Logical-semantic or semiotic level & Resistence - Invasion - Reclaiming territory - Criminalization. \\
\hline $\begin{array}{l}\text { Tetralemic-complexity level of } \\
\text { contents }\end{array}$ & $\begin{array}{l}\text { Mapuche community defends the attempts to install a hydroelectric plant in } \\
\text { Mapuche territory. }\end{array}$ \\
\hline
\end{tabular}

News 14: Title: Gobierno arremete contra las comunidades mapuche que realizan control productivo de tierras usurpadas.

\begin{tabular}{|l|l|}
\hline $\begin{array}{l}\text { Construction of the facts in the } \\
\text { discourse }\end{array}$ & $\begin{array}{l}\text { Chilean State defends the militarization in Mapuche territory and, at the } \\
\text { same time, accuses them of being violent. }\end{array}$ \\
\hline Roles, actors, time/space & Chilean Sate, Mapuche people, police, Judiciary. \\
\hline $\begin{array}{l}\text { Narratological level and narrative } \\
\text { paths }\end{array}$ & $\begin{array}{l}\text { Chilean State accuses Mapuche people who are recovering usurped terri- } \\
\text { tory as violent. }\end{array}$ \\
\hline Logical-semantic or semiotic level & Crime - Recuperation - Repression - Reclaiming territory. \\
\hline $\begin{array}{l}\text { Tetralemic-complexity level of } \\
\text { contents }\end{array}$ & Recuperation of territory that do not correspond to a crime. \\
\hline
\end{tabular}

News 15: Title: Carabineros, latifundistas y forestales destruyen y profanan ceremonial Mapuche en Trafun.

\begin{tabular}{|l|l|}
\hline $\begin{array}{l}\text { Construction of the facts in the } \\
\text { discourse }\end{array}$ & $\begin{array}{l}\text { Mapuche communities denounce a violent eviction and profanation of a } \\
\text { sacred Mapuche symbol by the police in a farm that is in the process of be- } \\
\text { ing recovered. }\end{array}$ \\
\hline Roles, actors, time/space & Mapuche communities and the Chilean Sate. \\
\hline $\begin{array}{l}\text { Narratological level and narrative } \\
\text { paths }\end{array}$ & $\begin{array}{l}\text { Chilean State represses and profane a sacred Mapuche symbol in re- } \\
\text { sponse to the occupation of farms by Mapuche communities as an act of } \\
\text { recovering usurped territory. }\end{array}$ \\
\hline Logical-semantic or semiotic level & Reclaiming territory - Usurpation - Reporting repression - Repression. \\
\hline $\begin{array}{l}\text { Tetralemic-complexity level of } \\
\text { contents }\end{array}$ & $\begin{array}{l}\text { Mapuche community suffered from a violent eviction and profanation of a } \\
\text { sacred Mapuche symbol in response of the process of recovering usurped } \\
\text { territory. }\end{array}$ \\
\hline
\end{tabular}

News 16: Title: Carabineros ingresa a comunidad de Ranquilko destruyendo viviendas y maltratando a mujer mapuche.

\begin{tabular}{|l|l|}
\hline $\begin{array}{l}\text { Construction of the facts in the } \\
\text { discourse }\end{array}$ & $\begin{array}{l}\text { Mapuche community is violently evicted by the police when occupying a } \\
\text { farm as an act of recovering usurped territory. }\end{array}$ \\
\hline Roles, actors, time/space & Mapuche communities and the Chilean police. \\
\hline $\begin{array}{l}\text { Narratological level and narrative } \\
\text { paths }\end{array}$ & $\begin{array}{l}\text { Chilean State suppresses Mapuche community in the process of recover- } \\
\text { ing usurped territory. }\end{array}$ \\
\hline Logical-semantic or semiotic level & Recuperation - Usurpation - Reporting repression - Repression. \\
\hline $\begin{array}{l}\text { Tetralemic-complexity level of } \\
\text { contents }\end{array}$ & $\begin{array}{l}\text { Chilean State and Forestal companies suppresses Mapuche communities } \\
\text { in the process of recovering usurped territory. }\end{array}$ \\
\hline
\end{tabular}


News 17: Title: Represión en Lof Rankilko, el alza de una militarización que busca acabar con la resistencia mapuche.

\begin{tabular}{|l|l|}
\hline $\begin{array}{l}\text { Construction of the facts in the } \\
\text { discourse }\end{array}$ & $\begin{array}{l}\text { Police violently evicted and broke into Mapuche community which was car- } \\
\text { rying out the process of recovering territory. }\end{array}$ \\
\hline Roles, actors, time/space & Mapuche community and the Chilean police. \\
\hline $\begin{array}{l}\text { Narratological level and narrative } \\
\text { paths }\end{array}$ & $\begin{array}{l}\text { Chilean State broke into Mapuche residences in order to suppress the pro- } \\
\text { cesses of recovering usurped territory by Mapuche communities. }\end{array}$ \\
\hline Logical-semantic or semiotic level & Reclaiming territory - Usurpation - Reporting repression - Repression. \\
\hline $\begin{array}{l}\text { Tetralemic-complexity level of } \\
\text { contents }\end{array}$ & $\begin{array}{l}\text { Chilean State broke into residences and evicted Mapuche people with the } \\
\text { purpose of avoiding the process of recovering usurped territory. }\end{array}$ \\
\hline
\end{tabular}

News 18: Title: Destrucción de viviendas y comuneros mapuches violentamente detenidos terminó desalojo desde predio Forestal.

\begin{tabular}{|l|l|}
\hline $\begin{array}{l}\text { Construction of the facts in the } \\
\text { discourse }\end{array}$ & $\begin{array}{l}\text { Violence and repression of the Chilean State when evicting Mapuche com- } \\
\text { munity in the Forestal Mininco company. }\end{array}$ \\
\hline Roles, actors, time/space & Mapuche community, Forestal Mininco company, Chilean police. \\
\hline $\begin{array}{l}\text { Narratological level and narrative } \\
\text { paths }\end{array}$ & $\begin{array}{l}\text { Chilean Sate supports repression and violence when evicting of the private } \\
\text { forestal company. }\end{array}$ \\
\hline Logical-semantic or semiotic level & Reclaiming territory - Usurpation - Reporting repression - Repression. \\
\hline $\begin{array}{l}\text { Tetralemic-complexity level of } \\
\text { contents }\end{array}$ & $\begin{array}{l}\text { Violence and repression when evicting Mapuche community in order to de- } \\
\text { fend private interests from the forestal companies settled in La Araucanía. }\end{array}$ \\
\hline
\end{tabular}

News 19: Title: Violenta acción del comando jungla de carabineros cobra primera víctima en comunidad de Temucuicui.

\begin{tabular}{|l|l|}
\hline $\begin{array}{l}\text { Construction of the facts in the } \\
\text { discourse }\end{array}$ & $\begin{array}{l}\text { Violence and repression of the Chilean State through trained police who } \\
\text { murder an innocent Mapuche farmer when coming back from his job. }\end{array}$ \\
\hline Roles, actors, time/space & $\begin{array}{l}\text { Mapuche communities. Police murder a disarmed and innocent Mapuche } \\
\text { farmer. }\end{array}$ \\
\hline $\begin{array}{l}\text { Narratological level and narrative } \\
\text { paths }\end{array}$ & Violent murder of an innocent Mapuche farmer working on the community. \\
\hline Logical-semantic or semiotic level & Violence - Assassination - Resistence - Repression. \\
\hline $\begin{array}{l}\text { Tetralemic-complexity level of } \\
\text { contents }\end{array}$ & $\begin{array}{l}\text { Police violently enter to the Mapuche community and murder a disarmed } \\
\text { Mapuche farmer. }\end{array}$ \\
\hline
\end{tabular}

News 20: Title: Héctor Llaitul denunció a las empresas forestales en las Naciones Unidas.

\begin{tabular}{|l|l|}
\hline $\begin{array}{l}\text { Construction of the facts in the } \\
\text { discourse }\end{array}$ & $\begin{array}{l}\text { The spokeman of the CAM (Mapuche group which reivindicates Mapuche } \\
\text { territory and culture) denounces the unscrupulous procedure of the Anghelini } \\
\text { group and Mininco forest companies that are becoming the second producers } \\
\text { of cellulose in the world. }\end{array}$ \\
\hline Roles, actors, time/space & Mapuche territory. Anghelini group and Mininco forest companies. \\
\hline $\begin{array}{l}\text { Narratological level and narrative } \\
\text { paths }\end{array}$ & $\begin{array}{l}\text { Chilean Sate supports repression and violence when evicting of the private } \\
\text { forestal company. }\end{array}$ \\
\hline Logical-semantic or semiotic level & Reclaiming territory - Usurpation - Resistence. \\
\hline $\begin{array}{l}\text { Tetralemic-complexity level of } \\
\text { contents }\end{array}$ & Denouncing the procedure of the forest companies in Mapuche territory. \\
\hline
\end{tabular}


News 21: Title: CAM se adjudica sabotaje en Curanilahue y llama a seguir en el camino de la resistencia y reconstrucción nacional Mapuche.

\begin{tabular}{|l|l|}
\hline $\begin{array}{l}\text { Construction of the facts in the } \\
\text { discourse }\end{array}$ & $\begin{array}{l}\text { Radical Mapuche group CAM sabotages some trucks in the Arauco for- } \\
\text { est company in order to protest against the assassination of an innocent } \\
\text { Mapuche farmer and also for calling Mapuche people to resist in the pro- } \\
\text { cess of reconstruction of the Mapuche nation. }\end{array}$ \\
\hline Roles, actors, time/space & Radical Mapuche group CAM. Arauco forest company. \\
\hline $\begin{array}{l}\text { Narratological level and narrative } \\
\text { paths }\end{array}$ & Violent eviction. Recuperation of territory. \\
\hline Logical-semantic or semiotic level & Occupation - Usurpation - Resistence - Repression. \\
\hline $\begin{array}{l}\text { Tetralemic-complexity level of } \\
\text { contents }\end{array}$ & $\begin{array}{l}\text { Radical Mapuche group confirms that sabotage of some trucks in the } \\
\text { Arauco forest company. }\end{array}$ \\
\hline
\end{tabular}

